\title{
MENUMBUHKAN MINAT MENELITI GURU DENGAN PENELITIAN TINDAKAN KELAS
}

\author{
Oleh: \\ Sugi Rahayu \\ FISE UNY
}

\section{Abstrak}

Masalah pendidikan di sekolah terjadi karena guru belum memiliki cukup kecakapan dalam memecahkan masalah. Guru orang yang paling berkepentingan dan paling mungkin untuk menemukan masalah dan berusaha memecahkannya sehingga pembelajaran berlangsung secara optimal. Salah satu upaya yang dilakukan untuk ini adalah penelitian tindakan kelas (PTK).

Penelitian tindakan kelas (PTK) salah satu jenis penielitian yang sangat bermanfaat untuk menggali masa!ah, mencari alternative pemecahan masalah, memberikan tindakan yang tepat, dan merefleksi hasil tindakannya sekaligus digunakan untuk peningkatan kualitas diri. PTK dilaksanakan sebagai suatı upaya meningkatkan efisiensi dan kualitas pendidikan, terutama proses dan hasil belajar siswa pada level kelas. PTK juga berguna bagi guru untuk menguji suatu teori pembelajaran. Melalui PTK guru dapat memilih dan menerapkan teori atau strategi pembelajaran yang paling sesuai dengan kondisi kelasnya. Dengan demikian, PTK adalah bentuk penelitian yang secara langsung dapat dimanfaatkan oleh guru.

Minat meneliti di kalangan guru perlu ditumbuh-kembangkan. Kemauan untuk belajar merupakan daya dorong yang kuat dari dalam diri guru. Penelitian merupakan kegiatan yang memiliki makna penting bagi seorang guru. Minat meneliti akan bertumbuh apabila ada dukungan dari luar diri guru, yaitu perhatian dari berbagai pihak terkait untuk meningkatkan kemampuan dan kualitas meneliti guru, misalnya mengadakan pelatihan penelitian dan memberikan kesempatan (khususnya pendanaan) kepada guru untuk melakukan penelitian.

Kata kunci: Minat Meneliti; Penelitian Tindakan Kelas

Pendahuluan

Guru merupakan salah satu komponen penting dalam menen- tukan keberhasilan pendidikan. Untuk itu, kualitas guru perlu senantiasa ditingkatkan sejalan 
dengan mutu pendidikan. Berbagai upaya telah dilakukan oleh pemerintah untuk meningkatkan kualitas guru. Salah satu upaya yang telah dilakukan adalah melalui peningkatan kemampuan me-nulis karya ilmiah. Kemampuan menu-lis karya ilmiah sangat bermanfaat bagi guru baik untuk dirinya sendiri maupun untuk kepentingan tugasnya sebagai pendidik. Penelitian adalah salah satu bentuk karya ilmiah yang perlu dikuasai oleh guru.

Penelitian merupakan kegiatan yang memiliki makna penting bagi seorang guru. Melalui kegiatan penelitian guru dapat mendemonstrasikan kemampuan penalarannya mulai dari pengenalan masalah sampai dengan pengambilan kesimpulan sebagai hasil dari analisis data yang dilakukannya, secara runtut dan sistematik. Apabila kegiatan tersebut diterapkan dalam proses pembelajaran tentunya akan sangat bermanfaat untuk meningkatkan kualitas pembelajarannya. Kemampuan meneliti juga sangat diperlukan agar guru mampu memperbaiki proses pembelajaran yang dilakukan.

Perkembangan ilmu pengetahuan, teknologi, dan seni (IPTEKS) yang begitu pesat saat ini tidak terlepas dari kegiatan penelitian karena berbagai kemajuan tersebut pada dasarnya merupakan temuan penelitian yang tak henti-hentinya dilakukan para pakàr dari berbagai disipiin ilmu. Di masa mendatang, penguasaan prin- sip-prinsip penelitian sekaligus kemampuan menerapkannya dalam memecahkan berbagai permasaahan hidup menjadi semakin pening, oleh karenanya harus dikuasai oleh setiap ilmuwan, termasuk di dalamnya adalah guru. Permasalaan yang dihadapi guru dalam proes pembelajaran harus mampu diarian solusinya oleh guru sendiri, karena mereka lah yang langsung berhadapan dengan anak didiknya. Salah satu jenis penelitian yang dapat dilakukan untuk kepentingan tersebut adalah penelitian tindakan kelas (PTK).

Masalah pendidikan di sekolah terjadi karena guru belum memiliki cukup kecakapan dalam memecahkan masalah yang ada. Guru adalah orang yang paling berkepentingan dan paling mungkin untuk menemukan masalah dan berusaha memecahkannya sehingga pembelajaran dapat berlangsung secara optimal. Salah satu upaya yang dapat dilakukan untuk ini adalah dengan melakukan penelitian tindakan kelas (PTK). Penelitian tindakan kelas (PTK) adalah salah satu jenis penelitian akan sangat bermanfaat untuk menggali masalah, mencari alternative pemecahan masalah, memberikan tindakan yang tepat, dan merefleksi hasil tindakannya sekaligus dapat digunakan untuk peningkatan kualitas diri dan karirnya. Oleh karena itu minat 
meneliti di kalanğan guru perlu ditumbuh-kembangkan.

Universitas Negeri Yogyakar-ta (UNY) sebagai sebuah Lembaga Pendidikan Tenaga Kependidikan (LPTK) yang salah satu tugasnya adalah menghasilkan calon guru dan tenaga kependidikan lainnya, menjadi bagian yang ikut andil dalam meningkatkan kemajuan dan kualitas pendidikan pada umumnya dan berusaha ikut aktif dalam peningkatan kualitas sumberdaya manusia (SDM) di bidang kependidikan. UNY melalui berbagai kegiatan baik di tingkat Fakultas maupun universitas berusaha menjalin kerjasama dan memberikan pelayanan kepada sekolah dalam upaya memecahkan masalah pendidikan yang ada di sekolah.

\section{Belajar sebagai Kebutuhan Hidup}

Belajar merupakan kebutuhan setiap orang sepanjang hidupnya. Belajar mempunyai pengertian yang luas. Belajar bukan saja aktivitas yang dilakukan di kelas. Belajar adalah aktivitas yang dilakukan seseorang yang belum memiliki pengetahuan dan kecakapan. Moh. Surya, memberikan definisi belajar sebagai suatu usaha yang dilakukan individu untuk memperoleh suatu perubahan tingkah laku yang baru secara keseluruhan sebagai hasil pengalaman individu itu sendiri dalam interaksinya dengan lingkungan (1981: 32).

Sejalan pendapat tersebut, Mulyasa (2003: 100), berpendapat bahwa pembelajaran pada hakikatya adalah proses interaksi antara peserta didik dengan lingkungannya sehingga terjadi perubahan perilaku ke arah yang lebih baik. Kegiatan pembelajaran di kelas adalah interaksi edukatif, yaitu kegiatan dua arah dan ada interaksi terus menerus antara pendidik (guru, dosen) dan peserta didik (siswa, mahasiswa).

Menurut Abdullah Idi peranan guru dalam melaksanakan proses belajar mengajar adalah: merencanakan unit pengajaran, mendiagnosis kesulitan belajar peserta didik, menguraikan kegiatan belajar yang sesuai, menghubungkan pengalaman belajar dengan minat peserta didik secara individual, mengorganisasikan kurikulum, dan mengevaluasi kemajuan peserta didik (1999: 160).

Berbagai pendapat ahli di atas menyatakan bahwa peran guru adalah sangat penting dalam pelaksanaan pembelajaran, di samping peserta didik adalah faktor penentu utama keberhasilan pelaksanaan pembelajaran. Peserta didik adalah subyek dan sekaligus objek dari program pembelajaran, sehingga jika peserta didik tidak mampu belajar dengan baik akan menghambat proses pembelajaran. Oleh karena itu sejak awal guru harus mempunyai sikap positif, motivasi dan berpartisipasi aktif dalam proses pembelajaran. Hal ini akan terjadi 
apabila guru mampu mengembangkan bidang keahliannya melalui kegiatan belajar secara terus menerus dan selalu mengikuti perkembangan di bidangnya. Penelitian adalah salah satu upaya yang dapat dilakukan guru untuk mengembangkan bidang keahlin yang ditekuninya. Bagi guru pendiikan seumur hidup (Long-Life Educaion) tetap merupakan sebuah kebutuan dan tantangan.

Penelitian ilmiah pada hakikatnya merupakan operasionalisasi metode ilmiah dalam kegiatan keilmuan. Demikian juga penulisan karya ilmiah, pada dasarnya merupakan argumentasi penalaran keilmuan yang dikomunikasikan lewat bahasa tulisan. Untuk itu mutlak diperlukan penguasaan yang baik mengenai hakikat keilmuan agar dapa: melakukan penelitian dan sekaligus mengkomunikasikannya secara tertulis.

Berdasarkan pengamatan dan wawancara dengan para guru dari berbagai jenjang pendidikan menun. jukkan bahwa minat meneliti para guru belum seperti yang diharapkan. Hal ini terlihat pada setiap ada tawaran penelitian untuk guru, mereka kurang antusias meresponsnya. Mereka merasa kurang berani menyusun proposal penelitian, padahal pada waktu kuliah mereka sudah mendapatkan matakuliah Metode Penelitian dan sudah menulis tugas akhir. Dengan kata lain minat meneliti para guru masih perlu ditumbuhkan.

\section{Minat Meneliti}

Banyak definisi tentang minat yang telah dikemukakan oleh para ahli. Menurut Ensiklopedi Pendidikan, minat adalah kesediaan jiwa yang bersifat aktif untuk menerima se-suatu dari luar (Sugarda Poerbatjaraka:, 1976: 182). Rangsang atau stimulus akan menimbulkan minat atau diterima oleh mekanisme penerimaan secara sadar dan aktif apabila stimulus tersebut menarik perhatian.

H.C. Witherington terjemahan M. Buchori, menyatakan bahwa minat adalah kesadaran sesecrang bahwa sesuatu objek, seseorang, suatu soal atau situasi mengandung sangkut paut dengan dirinya (1985: 134). Suatu hal akan menimbulkan minat seseorang apabila hal tersebut dapat dikaitkan dengan kehidupan pribadinya dan memberi manfaat bagi dirinya. Sesuai dengan pendapat ini bila siswa merasa belajar Penelitian Pendidikan mengandung sangkut paut dengan dirinya, maka akan memengaruhi kesadarannya. Menurut Crow dan Crow (1973: 153), minat merupakan kekuatan pendorong (motivation force), yang menyebabkan seseorang menaruh perhatian pada orang lain, pada aktivitas, atau objek lain.

WS Winkel mendefinisikan minat sebagai kecenderungan yang agak meningkat dalam subyek merasa tertarik pada bidang tertentu 
dan merasa senang berkecimpung dalam bidang itu. (1983: 30). Me-nurut Skinner (1958: 274), minat sebagai motif yang menunjukkan arah perhatian individu kêpada objek yang menarik. Objek yang menarik adalah objek yang menyenangkain. Dalam hal ini minat tidak berhenti sampai tahap perhatian saja tetapi ada tindakan lebih lanjut. Dari pendapat ini dapat disimpulkan bahwa apabila individu memerhatikan kegiatan meneliti sebagai suatu objek yang menyenangkan, maka ia cenderung berhubungan iebih aktif dengan objek di atas.

Sejalan dengan itu Bimo Walgito (1981: 38), mengatakan bahwa mirat adalah suatu keadaan dimana sestorang menaruh perhatian pada sesuatu dan disertai keinginan untuk mengetahui, mempelajari dan membuktikan lebih lanjut. Berdasarkan pendapat ini maka dapat dikatakan bahwa timbulnya minat untuk meneliti dikarenakan adanya perhatian terhadap objek tersebut terlebih dahulu.

Blum dan Balinsky (1973: 395) membedakan minat dalam dua kelompok yaitu minat subyektif dan minat objektif. Yang tergolong minat subyektif adalah perasaan senang dan tidak senang pada suatu objek yang timbul melalui pengalaman. Sedangkan minat objektif dijelaskan sebagai reaksi menerima atau menolak terhadap objek atau kegiatan-kegiatan di sekitarnya.

Jones (1963), menggolongkan minat menjadi dua bagian pula yaitu minat intrinsik dan minat ekstrinsik. Minat intrinsik adalah emosi senang terhadap nilai yang ada di dalam, sedang minat ekstrinsik berhubugan dengan rasa senang yang ditimbulkan oleh nilai yang berasal dari luar. Antara minat intrinsik dan minat ektrinsik seringkali sulit dibedakan.

Dari beberapa pendapat yang telah diketengahkan dapat disimpulkan bahwa minat adalah suatu keadaan dimana seseorang menaruh perhatian pada sesuatu dan disertai keinginan untuk mengetahui, memiliki, mempelajari dan membuktikan. Minat terbentuk setelah diperoleh informasi tentang objek atau kemauan dan keterlibatan perasaan, diiringi perasaan senang, terarah pada objek atau kegiatan tertentu dan terbentuk oleh lingkungan. Minat dapat menjadi pendorong ke arah keberhasilan seseorang karena orang yang berminat pada sesuatu bidang maka ia akan mudah untuk mempelajarinya.

Dengan demikian minat meneliti guru adalah suatu keadaan dimana guru menaruh perhatian pada penelitian dan disertai keinginan dengan perasaan senang untuk mengetahui, memiliki, mempelajari dan mempraktikkannya.

\section{Penelitian Tindakan Kelas}

Penelitian Tindakan Kelas (PTK) merupakan salah satu jenis penelitian tindakan yang dilaksana- 
kan oleh praktisi pendidikan (khususnya guru, dosen, atau instruktur) dalam proses pembelajaran di kelas. PTK dilakukan untuk memecahkan permasalahan pendidikan dan pembelajaran. PTK dilaksanakan sebagai salah satu upaya untuk meningkatkan efisiensi dan kualitas pendidikan, terutama proses dan hasil belajar siswa pada level kelas. PTK juga berguna bagi guru untuk menguji suatu teori pembelajaran. Melalui PTK guru dapat memilih dan menerapkan teori atau strategi pembelajaran yang paling sesuai dengan kondisi kelasnya. Dengan demikian PTK adalah bentuk penelitian yang secara langsung dapat dimanfaatkan oleh guru.

Penelitian Tindakan Kelas (PTK) atau Classroom Action Research (CAR) memiliki kandungan makna yang cukup banyak. Gunawan (2005: 2) mengemukakan beberapa pemaknaan terhadap PTK (CAR). PTK (CAR) dimaknai sebagai kegiatan dan atau tindakan perbaikan sesuatu yang perencanaan, pelaksanaan, dan evaluasinya digarap secara sistematik dan sistemik sehingga validitas dan reliabilitasnya mencapai ilmiah. Penelitian ini juga dimaknai sebagai pencarian kebenaran tindakan nyata upaya perbaikan suatu keadaan dengan menunjukkan hubungan sebab akibat. Lebih lanjut berdasar kandungan makna dalam PTK (CAR), Gunawan (2005:2) mendefinikan PTK (CAR) sebagai suatu upaya untuk meningkatkan kinerja komunitas melalui tahap pemahaman komunitas yang lebih luas dan lebih tajam terhadap sistem kerja yang ada dan meningkatkannya untuk lebih efektif dan efisien.

Penelitian tindakan merupakan implikasi nyata suatu tindakan untuk mengubah kondisi ke arah yang lebih baik. Tujuan classroom action research adalah memperbaiki kondisi dan atau meningkatkan kualitas yang ada sesuai masalah riil yang dihadapi secara professional. Di dalam penelitian ini terkandung suatu kerjasama antar kolabolator untuk mencapai tujuan yang diharapkan bersama. Berdasarkan hal itu, penelitian tindakan diartikan sebagai penelitian tentang, untuk, dan oleh masyarakat/ kelompok sasaran, dengan memanfaatkan interaksi, partisipasi, dan kolaborasi antara peneliti dan kelompok sasarannya sebagai upaya penyelesaian masalah dan proses pengembangan kemampuan dalam mendeteksi dan memecahkan masalah (Sukamto, dkk., 1999: 1).

Classroom action research adalah jenis pendekatan riset criticalism, suatu riset yang memandang pengetahuan itu di samping subyektif juga problematic. Penelitian ini menekankan pada pemikiran reflektif/kritis terhadap sesuatu hal yang mempengaruhi kualitas penelitian itu sendiri. Priyono (1999: 3-5) mengemukakan beberapa ciri 
Classroom action research sebagai berikut.

1) Masalah yang diteliti adalah masalah riil yang ada dihadapi (onthe job problem-oriented).

2) CAR berorienta'si pada pemecahan masalah (problem-solving orient-ted)

3) CAR berorientasi pada peningkatan kualitas (improvement orientted)

4) Di dalam CAR berbagai cara pengumpulan data dilakukan (multiple data collection)

5) CAR mengandung siklus (cyclic)

6) Adanya kolaborasi dalam CAR (partisipatory/collaborative).

Classroom action research merupakan salah satu cara strategis dalam perbaikan dan peningkatan layanan pendidikan, khususnya peningkatan layanan professional guru dalam menangani pembelajaran di sekolah. Persoalan-persoalan pendidikan dapat teratasi dengan refleksi dan diagnosis keadaan. Merefleksi adalah menganalisis, mensintesis, menginterpreasikan, dan mengeksplanasi yang diakhiri penyimpulan. Setelah itu dilakukan alternative tindakan dan dievaluasi hasilnya. Proses ini adalah siklus atau daur ulang yang terjadi dalam sebuah penelitian tindakan.

Banyak model penelitan tindakan, tetapi pada dasarnya setiap siklus dalam sebuah penelitian tindakan mengandung empat langkah, yaitu (1) perencanaan, (2) tindakan, (3) pengamatan atau observasi, dan (4) refleksi.
Salah satu model classroom action re-search adalah desain Kemmis \& Mc-Taggart (1990: 14), pelaksanaan penelitian tindakan mencakup langkah: (1) merumuskan masalah dan merencanakan tindakan, (2) melaksanakan tindakan dan monitorring/pengamatan, (3) refleksi hasil pengamatan, (4) revisi perencanaan untuk siklus selanjutnya.

Selain itu, John Elliot (1991) dalam Sukamto, dkk., 1999: 22-23) juga mengembangkan konsep Kurt Lewin dengan desain yang lebih rinci.Terdapat tiga tindakan dalah setiap siklusnya.. Siklus pertama diawali dengan penemuan ide awal lalu dianalisis permasalahannya dan dilakukan perencanaan. Selanjutnya dilakukan implementasi tindakan dan monitoringnya. Berdasarkan monitoring dilakukan dilakukan penjelasan kegagalan dan revisi perencanaan untuk perbaikan, dan selanjutnya dilakukan tindakan lagi, dan seterusnya.

\section{Membiasakan Guru Melakukan Penelitian}

Melakukan penelitian sebagai salah satu bentuk penulisan karya ilmiah bukanlah pekerjaan yang mudah. Untuk dapat melaksanakan penelitian dengan benar diperlukan pemahaman tentang konsep dan prinsip-prinsip penelitian. Penelitian adalah kegiatan yang sepenuhnya menerapkan pola fikir ilmiah dalam setiap langkah 
yang dilakukan. Melalui kegiatan penelitian orang dapat menunjukkan kemampuan dalam memecahkan masalah secara ilmiah mulai dari pengenalan masalah sampai dengan pengambilan kesimpulan sebagai hasil dari analisis data yang dilakukannya (Muhyadi, 2002: 1).

Kegiatan penelitian merupakan gabungan antara pola berfikir deduktif dan induktif. Secara garis besar, langkah-langkah dalam suatu proses penelitian meliputi: (1) pengajuan masalah, (2) pengkajian pustaka, penyusunan kerangka berfikir dan hipotesis atau pertanyaán penelitian, (3) penentuan metode penelitian dan penyusunan instrumen, (4) pengumpulan data, (5) analisis data, (6) penyajian hasil dan pembahasan, (6) penarikan kesimpulan dan saran. Hasil penelitian kemudian disusun dalam bentuk laporan penelitian dengan menggunakan sistematika tertentu.

Perkembangan ilmu dan teknologi yang begitu pesat sebagaimana dapat disaksikan sekarang ini tidak terlepas dari kegiatan penelitian. Berbagai kemajuan tersebut pada hakikatnya merupakan hasil penelitian yang tak henti-hentinya dilakukan para pakar dari berbagai disiplin ilmu.

Guru sebagai pendidik sekaligus pengembang ilmu harus memahami konsep dasar dan mampu melaksanakan penelitian ilmiah. Di samping itu, agar dapat menuangkan hasil penelitian dalam suatu karya tulis ilmiah guru juga harus memahami kaidah-kaidah penulisan ilmiah. Hal ini tentu saja bukan pekerjaan mudah karena selama ini kesempatan meneliti guru sangat terbatas. Beberapa hal yang perlu diketahui oleh penulis pemula dalam menuangkan ide meliputi: objektifitas, sistematika penulisan, dukungan data pembenaran, dan penggunaan bahasa baku yang lugas (Soemantri W., 2003: 22-23).

Menurut Zamzani (2004: 4), tulisan ilmiah adalah tulisan yang didasari hasil pengamatan, peninjauan, atau penelitian dalam bidang tertentu, disusun menurut metode tertentu dengan sistematika penulisan yang bersantun bahasa dan isinya dapat dipertanggungjawabkan kebenarannya. Selanjutnya dijelaskan, suatu tulisan disebut karya tulis ilmiah apabila memenuhi persyaratan: (1) isi kajiannya berada dalam lingkup pengetahuan imiah, (2) langkah pengerjaannya dijiwai atau menggunakan metode ilmiah, (3) sosok tampilannya sesuai dan memenuhi syarat sebagai sosok keilmuan. Dengan demikian metode ilmiah merupakan dasar pijak untuk tulisan ilmiah.

Ada empat komponen utama dalam metode ilmiah, yakni: masalah, hipotesis, verifikasi, dan kesimpulan. Metode ilmiah dapat menggunakan alur berfikir deduktif dan induktif. (Zamzani, 2005: 4). Penalaran deduktif digunakan untuk menyusun kerangka pikir dalam me- 
mecahkan masalah yakni dengan mendasarkan diri pada teori-teori dan hasil kajian yang telah ada. Penalaran induktif digunakan ketika kita ingin menguji adanya kebenaran suatu pernyataan yang rasional dengan memanfaatkan fakta empiris. Sebuah pernyataan dianggap benar jika didukung fakta empiris.

Menurut Ekosusilo dar. Triyanto (1995), ciri-ciri tulisan ilmiah adalah: (1) logis, (2) sistematis, (3) objektif, (4) tuntas dan menyeluruh, (5) seksama, (6) jelas, (7) kebenarannya teruji, (8) terbuka, (9) berlaku umum, (10) penyajiannya memperhatikar. santun bahasa dan tata tulis yar.g sudah baku.

Berdasarkan kajian teoretik di atas, maka dapat dikemukakan kerangka berfikir bahwa minat untuk meneliti dapat ditumbuhkan. Apabila individu memperhatikan kegiatan meneliti sebagai suatu objek yang menyerangkan, maka ia cenderung berhubungan lebih aktif dengan objek tersebut, sehingga timbul keinginan untuk mengetahui, memiliki, mempelajari dan mempraktikkannya. Prinsip learning by doing dan practice makes perfect dalam kegiatan penelitian yang berupa praktik menyusun proposal penelitian secara bertahap dan terbimbing dapat menumbuhkan minat meneliti guru. Proposal yang telah disusun secara bertahap dan terbimbing dapat dikembangkan menjadi penelitian adalah merupakan daya dorong bagi minat meneliti guru.
Salah satu dari sekian banyak tujuan penelitian adalah kebermanfaatan atas hasil penelitian tersebut. Salah satu penelitian yang da-pat dirasakan secara langsung marıfaatnya adalah penelitian tindakan kelas atau classroom action re-search. Classroom action research atau penelitian tindakan kelas (PTK) merupakan bentuk penelitian yang berbasis pada upaya penyelesaian masalah. Penelitian ini tidak ambisius untuk menggeneralisasikan temuan, tetapi lebih focus pada pemecahan masalah riil yang dihadapi di lapangan. Jenis penelitian ini sangat tepat diakukan oleh nuru untuk mengubah kondisi kea rah yang lebih baik, terutama dalam proses pembelajaran di kelas.

Dalam hal seperti ini guru harus berusaha proaktif menjalin kerja sama dengan berbagai pihak untuk belajar dan melakukan kolaborasi untuk mengadakan penelitian terhadap permasalahan yang dihadapi dalam kegiatan pembelajarannya. Di samping itu guru selalu mengikuti pelatihan terkait dengan penelitian dan atau penulisan ilmiah yang banyak diselenggarakan oleh berbagai lembaga pendidikan tinggi.

\section{Penutup}

Penelitian Tindakan Kelas
(PTK) atau Classroom action
research (CAR) merupakan salah


satu jenis penelitian tindakan yang dapat dilaksanakan oleh guru se-laku praktisi pendidikan. PTK dila-kukan untuk memecahkan permasa-lahan pendidikan dan pembelajaran. PTK dilaksanakan sebagai salah satu upaya untuk meningkatkan efisiensi dan kualitas pendidikan, terutama proses dan hasil belajar siswa pada level kelas. PTK juga berguna bagi guru untuk menguji suatu teori pembelajaran. Melalui PTK guru dapat memilih dan menerapkan teori atau strategi pembelajaran yang paling sesuai dengan kondisi kelasnya. Dengan demikian PTK adalah bentuk penelitian yang secara langsung dapat dimanfaatkan oleh guru.

Minat meneliti para guru masih harus ditumbuhkan sehingga pihak pemangku kepentingan (stakeholder) perlu mengambil bagian dalam masalah ini antara lain dengan mengadakan berbagai pelatihan dan kesempatan meneliti kepada mereka.

\section{Daftar Pustaka}

Blum, Milton L. dan Balinsky, Benjamin. 1973. Counseling and Psychology.

Tokyo: Charles E. uttle Company.

Bimo Walgito. 1984. Psikologi Sosial. Yogyakarta: Andi Offset.

Crow Lester D. dan Crow, Alice. 1973. An Outline of General Psychology.

New York: Littlefiled, Adam and $\mathrm{Co}$.
Departemen Pendidikan dan

Kebudayaan, 1999,

Penelitian Tindakan, Jakarta,

Ditjen Dikti Depdikbud.

Djihad Hisyam. 1998. Evaluasi

Pelaksanaan Pendidikan

SMU Unggul di SMU

Negeri 1 Yogyakarta. Tesis.

Yogyakarta PPs. IKIP

Yogyakarta.

Ekosusilo, M. dan Triyanto, B. 1995. Pedoman Penulisan

Karya Ilmiah. Semarang:

Dahara Prize.

Jones, A.J. 1963. Princiles of Guidance. New York: McGraw-Hill Book

Company.

Mochtar Buchori. 1985. IImu Pendidikan dalam Renungan. Jakarta: IKIP

Mohammadiyah Jakarta

Press.

Muhyadi, 1997, "Model-Model

Pembelajaran dalam rangka

Penelitian Tindakan

Kelas", Makalah disampaikan dalam Lokakarya PTk Guru SD Lab PGSD.

-, 2002. 'Kajian Pustaka dan

Penyusunan Kerangka

Berfikir dalam Proses

Penelitian", Makalah

disampaikan pada Forum

Bimbingan Penulisan Lomba

Karya Tulis IImiah Mahasiswa

FIS UNY , 5 April 2002. 
Mulyasa. 2003. Kurikulum Berbasis

Kompetensi. Bandung: PT

Remaja

Rosdakarya.

Soemadi Surjabrata, 1980, Psikologi

Pendidikan, Yogyakarta: Raka Press.

Soemantri Wardoyo. 2003. "Menulis

Karya IImiah". WUNY, edisi Mei 2003.

Zamzani, dkk. 2004. "Peningkatan Keterampilan Penulisan Karya IImiah Bagi

Mahasiswa UNY Melalui

Peningkatan Perkuliahan

Bahasa Indonesia".

Laporan Penelitian. Yogyakarta:

Lembaga Penelitian UNY.
Universitas Negeri Yogyakarta. 2003. Pedoman Penulisan Tugas Akhir. Yogyakarta: UNY.

Skinner, C.E. 1958. Essential of Fundamental Psychology. New York: Prentice Hall Inc.

Sugardá Poerbatjaraka. 1982. Ensiklopedi Pendidikan. Jakarta: PT Gunung Agung.

Winkel, WS. 1983. Psikologi Pendidikan dan Evaluasi. Jakarta: PT Gramedia.

Biodata Penulis

Nama lengkap penulis adalah Sugi Rahayu, salah satu staf pengajar pada Jurusan Pendidikan Administrasi Fakultas IImu Sosial dan Ekonomi, Universitas Negeri Yogyakarta 